\title{
Create Your Own Constitutional Theory
}

\author{
Michael C. Dorf $\dagger$
}

Critics of constitutional pragmatism, such as Professor Fallon, argue that courts should not decide constitutional cases simply by asking what outcome is best, all things considered. Such an approach, the critics contend, does not permit constitutional adjudication to advance values associated with democracy, the rule of law, and individual rights. This Reply to Professor Fallon's article in this issue argues that the critics are right to reject pure adjudicatory instrumentalism, but that a different conception of pragmatism should inform constitutional interpretation. Early twentiethcentury American philosophers used the term pragmatism to mean understanding a practice by participating in it rather than theorizing about it. Applied to constitutional law, this notion of pragmatism-as-contextualism makes instrumentalism safe for interpretation, for it allows instrumental considerations to be weighed within the felt-but-difficult-to-define constraints imposed by constitutional practice. In endorsing constitutional pragmatism-as-contextualism, this Reply challenges Professor Fallon's suggestion that judges and constitutional scholars should "choose" constitutional theories that they then use to resolve concrete disputes. Instead, this Reply argues that theories of constitutional interpretation emerge from considered, contextual judgments about particular cases.

\section{INTRODUCTION}

In his thoughtful and thought-provoking article, How to Choose a Constitutional Theory, ${ }^{1}$ Professor Fallon offers assistance to those bewildered by the large number and variety of constitutional theories. His insightful account sheds light on what is at stake in the constitutional theory debate, showing the premises shared by its participants. Nonetheless, I am

Copyright $\odot 1999$ California Law Review, Inc.

t Vice-Dean and Professor of Law, Columbia University School of Law. I greatly benefited from the comments of participants in a workshop at the Vanderbilt Umiversity School of Law. I am also grateful to George Fletcher, Kent Greenawalt, Andrzej Rapaczynski, Joseph Raz, and Jeremy Waldron for helpful discussions, and to Cbarles Honig for research assistance. (1999).

1. Richard H. Fallon, Jr., How to Choose a Constitutional Theory, 87 Calif. L. REv. 535 
dubious about Fallon's basic undertaking. The title suggests that the choice of a constitutional theory precedes the formulation of answers in particular cases:-one chooses a constitutional theory and then applies it to constitutional cases. Yet in practice, matters typically proceed in the opposite direction.

Before I had views about constitutional theory, I had views about constitutional law. I thought that judicial review was a fair inference from the Constitution's text, structure, and history, even though I thought John Marshall's argument in Marbury v. Madison ${ }^{2}$ question-begging; I thought the post-New Deal but pre-United States v. Lopez ${ }^{3}$ construction of the Commerce Clause too generous, given Article I's evident strategy of limiting national authority by enumerating specific powers; I thought the Court should ground its unenumerated-rights jurisprudence in the Ninth Amendment and the Privileges or Immunities Clause (and thus overrule the Slaughter-House Cases $^{4}$ ), rather than continue to rely on the Due Process Clauses; and so on. I lacked a theory of constitutional interpretation, not because I believed I did not need one, nor because I did not realize that my views about concrete constitutional doctrines were imterpretive. ${ }^{5} \mathrm{I}$ lacked a theory of interpretation because, at least in the beginning, I did not know enough about the practice of constitutional law to be able to evaluate theoretical claims about that practice.

I very much doubt that my experience was unusual. By the time anyone has occasion to think about constitutional theory, she will likely have views about a fairly wide range of constitutional issues. At that point, choosing a constitutional theory is a matter of finding one that fits these views. "Fit" will have both descriptive and normative elements, if only because one's views about concrete issues themselves combine descriptive and normative elements.

To say that one fits constitutional theory to one's views about concrete constitutional issues is not to say that constitutional theory then plays no role in what one thinks about subsequent cases. Once one settles on a constitutional theory that comes close to fitting her views on concrete issues, a judge or academic may find that the theory leads her to change her views on some of these issues, which in turn may lead to adjustments to the theory, and so forth, until a "reflective equilibrium"' is reached.

However, it will be the rare judge or academic that self-consciously goes through this process of trying on different theories. Even among those

2. 5 U.S. (1 Cranch) 137 (1803).

3. 514 U.S. 549 (1995).

4. 83 U.S. (16 Wall.) 36 (1872).

5. I was not, in other words, in an unquestioning, pre-interpretive stage of constitutional practice. See RONALD DWORKIN, LAW's EMPIRE 47 (1986) (describing the pre-interpretive stage of a hypothetical social practice of courtesy).

6. See JohN RAWLS, A THEORY OF JUSTICE 48-51 (1971). 
who do, in most instances the theory upon which she settles will rarely lead to substantially different results from those she favored before she engaged in the search for a theory. These are empirical assertions, I recognize, and I have conducted nothing like a comprehensive study of the ways in which judges and academics form doctrinal and theoretical views; nonetheless, I venture that they will ring true for anyone who has observed the practice of constitutional law.

Notwithstanding the awkward metaphor of "choice,"m soine places im his article, Fallon could be read to agree with the account I have just given. For example, he writes that he aims "to provide a framework within which readers can determine how various constitutional theories should be assessed in light of their own views about the rule of law, political democracy, and the individual rights necessary for substantive justice." Because no two participants in the debates about constitutional law and constitutional theory will have identical views about these inatters, there will be as many constitutional theories as there are people who care to think about constitutional theory. Of course, if the adoption of a constitutional theory proceeds im the way I have just described, "choosing" is an inapt description. One does not choose a constitutional theory like a suit off the rack; one tailors constitutional theory to one's own views, including one's views as they are modified by the mitial selection of a theory.

But I do not merely wish to take issue with the title of Fallon's article. Instead, iny basic disagreement is with the size of the categories that Fallon employs in his analysis of constitutional theory. "Alnost without exception," he states, constitutional "theorists claim that their preferred approaches optimally realize sometimes coinpeting values associated with (i) upholding the rule of law, (ii) promoting political democracy, and (iii) advancing substantive justice by respecting a morally defensible set of individual rights. ${ }^{\prime 2}$ Fallon treats these values as the criteria by which to evaluate or choose a constitutional theory. In this Reply, I argue that these values are simply too encoinpassing to provide a useful window into the constitutional theory debate. I contend that both the differences that divide and the common ground that unites various constitutional theorists can be found in the concrete practices of constitutional interpretation.

The perspective on constitutionalism that I advance here is pragmatist in the sense that philosophers use that term-namely, the view that one understands institutions and practices by participating in them according to their own (corrigible) rules, rather than by pondering them from the

7. Fallon, supra note 1 , at 551 .

8. Cf. Frederick Schauer, The Supreme Court, 1997 Term, Comment: Principles, Institutions, and the First Amendment, 112 HARv. L. REv. 84, 109 (1998) (describing the tendency of jurisprudents to associate law with large categories).

9. Fallon, supra note 1, at 549-50. 
outside. ${ }^{10}$ Fallon offers an argument against a different sort of pragmatism-the view that "judges should simply decide cases in whatever way will produce the best future results." There is no necessary connection between this notion of legal pragmatism and philosophical pragmatism. The former is a form of instrumentalism, the latter a form of contextualism. ${ }^{12}$ One can find Fallon's arguments against pure adjudicatory instrumentalism persuasive, but still believe that the best way to make sense of constitutional practice is to participate in it, rather than theorize about it.

In any event, pure adjudicatory instrumentalisin is a straw man. From the premise that adjudication should not proceed on purely instrumental grounds, Fallon draws the conclusion that the interest in effective government should play at most a subsidiary role in evaluating a constitutional theory. ${ }^{13} \mathrm{He}$ does so primarily because he worries about the rule-of-law implications of having judges inake what appear to be unconstrained policy judgments. Yet it is here that Fallon's failure to consider the possibility of pragmatism-as-contextualism undermines his argument. For the practice of constitutional adjudication acts as a constraint on the scope that may be given to instrumental considerations, and thus makes adjudication safe for instrumentalisin.

My critique proceeds against this backdrop. Part I inquires into the ontology of Fallon's article. In inaking claiuns about constitutional theory, Fallon offers a meta-theory of constitutional law. Yet, for reasons I shall explore, and despite Fallon's contention to the contrary, ${ }^{14}$ Fallon's metatheory is itself a kind of constitutional theory, and can therefore be judged as such. Although not obviously wrong, I argue that Fallon's meta-theory

10. The leading pragmatist texts are JoHN DEWEY, LogIC: THE THEORY OF INQUIRY (1938); William JAMES, PRagmatism (1907); and Charles S. Pierce, How to Make Our ldeas Clear, reprinted in Pragmatism: A Reader 26 (Louis Menand ed., 1997). Two leading neo-pragmatist texts are Richard J. Bernstein, Beyond Objectivism and Relativism: Science, Hermeneutics, and PRAXIS (1983), and RICHARD RORTY, CONSEQUENCES OF PRAGMATISM (1982). Although not ordinarily considered a pragmatist, Wittgenstein, especially in his later work, expressed similar views about the primacy of practice. See LUdWIG WITTGENSTEIN, PhILosophical INvestigations §§ 198-201 (G. E. M. Anscombe trans., $3 d$ ed. 1958).

11. Fallon, supra note 1 , at 564 . Rouald Dworkin uses the term "pragmatism" in roughly the same way that Fallon does. See Dworkin, supra note 5, at 160 ("Pragmatism... says that judges should follow whichever method of deciding cases will produce what they believe to be the best community for the future.").

12. In denying a necessary connection between instrumentalism and contextualism, I do not deny that the proponents of American philosophical pragmatism-as-contextualism also endorsed instrumentalism. See, e.g., William James, What Pragmatism Means, in PragmatisM (1907), reprinted in PRAGMATISM: A READER, supra note 10, at 93, 98 ("[T] he pragmatic method means ... looking away from first things, principles, 'categories,' supposed necessities; and of looking towards last things, fruits, consequences, facts.").

13. See Fallon, supra uote 1, at 559 (arguing that the interests in workable government and economic efficiency should be subsumed within the rubrics of fit, political democracy, and individual rights).

14. See id. at 551 ("[N]or do I advance a constitutional theory of my own."). 
is not especially persuasive either, principally because the existence of consensus is at best a weak reason for anyone to adopt consensus views. Part II continues the exploration of the consensus Fallon identifies. I argue that the agreement among constitutional theorists about the importance of Fallon's three criteria is too thin to establish his descriptive claim that various constitutional theorists "are not simply talking past each other."15 Part III expands upon Fallon's three evaluative criteria and argues that considerations of governmental efficacy play a larger role in constitutional adjudication (and thus constitutional theory) than Fallon's account recognizes. Part IV returns to the relation between legal pragmatism and philosophical pragmatism. I argue that were Fallon to embrace the latter-pragmatismas-contextualism - he would be able to give a more prominent role to considerations of efficacy im his account of constitutional theory and constitutional law.

I

\section{META-THEORY AND THEORY}

Fallon divides constitutional theories along two principal axes. First, he distimguishes between constitutional theories that aim to fit the constitutional text and theories that aim to fit the Supreme Court's constitutional practice. ${ }^{16}$ Second, he distinguishes between formal constitutional theories that prescribe interpretive methodologies and substantive constitutional theories that directly advance some constitutional value. ${ }^{17}$ Notwithstanding these deep divisions, and despite equally deep divisions within each category ${ }^{18}$ Fallon contends that there is substantial consensus about the goals of constitutional theory. Constitutional theorists, he argues, all seek to advance the three values he identifies, albeit im different ways and to different relative degrees. Thus, he argues, these values-the rule of law, democratic legitimacy, and individual rights-can serve as the criteria of a constitutional meta-theory.

Fallon's meta-theory captures something important about the constitutional theory debate. Virtually all theories of constitutional interpretation give some substantial role to each of Fallon's three criteria. However, as I argue at greater length in Part II, they do so in critically different ways. For

15. Id. at 550 .

16. See id. at $541-44$.

17. See id. at 562-68.

18. For example, the category of substantive theories includes such strange bedfellows as Richard Epstein's economic libertarianism, see Richard A. Epstein, Takings: Private Property AND THE POWER OF EMINent Domain (1985), David Richards's Rawlsian liberalism, see David A. J. Richards, Toleration AND THE Constitution (1986), and perhaps John Hart Ely's representationreinforcement, see John Hart Ely, Democracy and Distrust: A Theory of Judicial Review (1980). See Fallon, supra note 1, at 554, 559 n.134 (suggesting that Ely's theory is arguably substantive). 
example, Justice Scalia and Judge Bork treat rule-of-law values as a trumping principle; ${ }^{19}$ Bruce Ackerman and John Ely assign that role to democratic legitimacy; ${ }^{20}$ while David Richards, Lawrence Sager and arguably Ronald Dworkin ${ }^{21}$ give pride of place to rights. Still other theorists, like Philip Bobbitt and myself, deny that there can be all-purpose trumping primciples by which the Constitution can be interpreted. ${ }^{22}$

These are not merely questions of degree. Each constitutional theorist assigns his or her own priorities or weights to each of the three constitutional values that Fallon identifies. To decide which theory is best, we need some means of measuring each constitutional theory's assignment of priorities and weights against the "best" assignment of priorities and weights. There is, however, no consensus about what assignment is best. Any claim that some set of priorities and weights is best is itself a highly contestable claim of constitutional theory. As Fallon himself states: "Questions about appropriate evaluative criteria for constitutional theories arise within the same debates in which those criteria are mvoked. ${ }^{223}$ In other words, a claim about constitutional theory is necessarily also a claim of constitutional theory. Despite Fallon's protestations, the meta-theory he advances is thus also a constitutional theory.

If I am correct in treating Fallon's meta-theory as also a theory, then it potentially supplies the criteria for its own evaluation. Should one choose How to Choose a Constitutional Theory as her own constitutional theory? We might usefully apply the criteria set forth in the article itself. Of course, if the ineta-theory points to itself as the proper theory, that fact alone

19. See Robert H. Bork, The Tempting of America: The Political Seduction of the LAW 318 (1990) (describing originalism as "essential if courts are to govern according to the rule of law"); ANTONIN Scalia, A MATTER OF INTERPRETATION 25 (Amy Gntman ed., 1997) ("Long live formalism. It is what makes a government a government of laws and not of men.").

20. See Bruce Ackerman, 1 We the People: Foundations 6 (1991) (describing "dualist democracy," $m$ which the Constitution derives its legitimacy from adoption by the Peoplc); ELY, supra note 18, at 73-75, 101-04 (describing the Constitution's role as facilitating democracy).

21. See Ronald Dworkin, Freedom's Law: The Moral Reading of the American ConstituTion 7-8 (1996) ("[G]overnment must treat all those subject to its dominion as having equal moral and political status."); RICHARDS, supra note 18, at 149 (arguing that particular rights derive from substantive principles of freedom of conscience that "speak to contemporary democratic concerns about moral independence in a mass society directly and vitally"); Lawrence G. Sagcr, Justice in Plain Clothes: Reflections on the Thinness of Constitutional Law, 88 Nw. U. L. REv. 410, 416 (1993) (offering a "justice-seeking" account of constitutional interpretation).

22. See PhILIP BobBitT, Constitutional INTERPRETation 131-54 (1991) (contending that any effort to identify an algorithm for deciding disputes among constitutional arguments leads to an infinitc regress); Micbael C. Dorf, Integrating Normative and Descriptive Constitutional Theory: The Case of Original Meaning, 85 GEO. L.J. 1765, 1794 (1997) (agreeing with Bobbitt that there can be no allpurpose algorithm, but disagreeing with other elements of his approach). Ronald Dworkin arguably belongs in this pluralist or eclectic camp rather than in the rights-foundationalist camp becausc Dworkin has emphasized the responsibility that judges bave to fit their vision of political justice within the existing legal framework. See generally DworkIN, supra note 5, at 225-75 (describing the role of "integrity" in law).

23. Fallon, supra note 1, at 551. 
cannot establish the theory's correctness. This would be a form of bootstrapping. On the other hand, if the theory cannot satisfy its own criteria, that is a powerful reason to doubt its correctness.

What kind of theory is How to Choose a Constitutional Theory? In addition to dividing constitutional theories along the text/practice and for$\mathrm{mal} / \mathrm{substantive} \mathrm{axes,} \mathrm{Fallon} \mathrm{considers,} \mathrm{but} \mathrm{then} \mathrm{rejects,} \mathrm{a} \mathrm{division} \mathrm{between}$ descriptive and normative constitutional theories. ${ }^{24} \mathrm{He}$ states: "Few, if any, constitutional theories are purely normative.... But few constitutional theories are purely descriptive either. ${ }^{325}$ The same appears to be true of Fallon's (meta-)theory. In defending his three criteria, Fallon relies on what he understands to be a consensus among constitutional theorists. In this sense, Fallon's meta-theory is descriptive. But Fallon also argues that his three criteria are the proper ones, and in this sense his meta-theory is normative.

Although Fallon's meta-theory straddles the descriptive/normative divide, it takes a clear stance on the text-based/practice-based line. His meta-theory aims only at practice. He derives his three criteria from the practice of constitutional theory, as found in the writings of legal scholars and prominent jurists. Fallon acknowledges that constitutional theory could, in principle, be derived from constitutional text. He states that "the People of the United States, by constitutional amendment, could prescribe a constitutional theory to be applied by courts, ${ }^{206}$ but presumably he believes that We the People have not yet done so. Is he correct? In an obvious sense, yes: the Constitntion contains no clause expressly prescribing a single interpretive methodology to be applied in all cases. The constitutional text is, however, hardly silent on questions of interpretation. The Ninth Amendment provides a faumliar example. " $[\mathrm{I}] \mathrm{t}$ is a rule of interpretation.... It tells each reader: whatever else you're going to do ... you cannot advance [an] argument that [unenumerated] rights are not [protected by the Constitution] just because they are not enumerated in the Bill of Rights."27 Accordingly, a text-based approach to constitutional meta-theory would give substantial weight to the language of the Ninth Amendment, at least in rights cases. ${ }^{28}$

24. See id. at $540-41$.

25. Id.

26. Id. at 576 .

27. Laurence H. Tribe \& Michael C. Dorf, On Reading the Constitution 54 (1991).

28. Of course, there is considerable irony in a text-based meta-theory's focus on the Ninth Amendment. As Fallon notes, advocates of text-based approaches to constitutional theory tend to place great weight on the values of rule-of-law and democratic legitimacy. They invoke constitutional text in the hope of providing a relatively fixed meaning which constrains unelected judges' discretion to displace decisions of majoritarian bodies. Yet in the case of the Ninth Amendment, "the only rule of interpretation explicitly stated in the Constitution," id., a text-based approach leads in the direction of soinething like judicially discoverable and enforceable natural law. See, e.g., Calvin R. Massey, The Natural Law Component of the Ninth Amendment, 61 U. CIN. L. REv. 49, 50 (1992) (arguing that the 
Various other provisions of the Constitution's text could also be thought to provide considerable guidance on questions of interpretation. The Constitution aims, in the words of the Preamble, to "establish Justice, insure doinestic Tranquillity, provide for the common defense, proinote the general Welfare, and secure the Blessings of Liberty ...."29 A text-based meta-theory of constitutional interpretation might use these textual values as. guides. To be sure, these values are somewhat indeterminate, but no more so than Fallon's three legitinacy criteria.$^{30}$ A quite different textbased meta-theory might emerge if one used the Tenth Amendinent and the deep structure of enumerated powers to make state sovereignty the Ur-primciple of constitutional interpretation. I do not endorse or defend any of these possibilities here. I only note that Fallon overlooks plausible textbased alternatives when he looks only to the practice of constitutional theory for the principles by which to evaluate constitutional theory.

To say that Fallon's meta-theory is practice-based rather than textbased is not necessarily to criticize. The fact that a text-based meta-theory is possible does not, after all, mean that such a theory is best. Nonetheless, Fallon's construction of a practice-based meta-theory of constitutional interpretation is curious. Why should anyone care whether there exists consensus about the values various constitutional theories advance? Suppose that I proffer the following theory of interpretation: the Justices should decide every case in the manner they believe will, in the long run, nnaximize the welfare of the least fortunate members of society. ${ }^{31}$ What can Fallon say to convince me that this is the wrong constitutional theory? He would most likely argue, as he indeed does argue in response to what he

Constitution's text allows a role for natural law, and that the Founders so intended); David N. Mayer, The Natural Rights Basis of the Ninth Amendment: A Reply to Professor McAffee, 16 S. ILL. U. L.J. 313, 313 (1992) (advocating a "Natural Law' reading of the amendment"); Suzanna Sherry, The Founders' Unwritten Constitution, 54 U. CHI. L. REv. 1127, 1164-66 (1987) (arguing that the Ninth Amendment reflected the Founders' belief in natural law). But see Thomas B. McAffee, The Original Meaning of the Ninth Amendment, 90 Colum. L. Rev. 1215, 1218-23 (1990) (defending the "traditional" interpretation of the Ninth Amendment as simply reaffirming that the fedcral government has no powers beyond those enumerated).

29. U.S. CONST. preamble.

30. One might object to seeking interpretive aids in the Preamble on the ground that constitutional theories (and meta-theories) are supposed to provide guidance for judicial interprctation, whereas the Preamble appears to be addressed principally to political actors. Yet even if the Preamble does not, by itself, create justiciable entitlements, it does not follow that the Preamble should play no role in constitutional interpretation. After all, Fallon's own three preferred values also do not creatc justiciable entitlements. The values that inform constitutional theory need not themselves create constitutional rights or otherwise directly decide constitutional controversies. It is sufficient that they provide guidance, and we might find such guidance in the Preamble. The Preamble sets forth values that could be used in aid of interpretation of justiciable provisions. See, e.g., Charles L. Black, Jr., Further Reflections on the Constitutional Justice of Livelihood, 86 CoLUM. L. REv. 1103, 1105-08 (1988) (turning to the Preamble and the Declaration of Independence as sources of guidance).

31. See, e.g., RAwLs, supra note 6, at 75 ("[T] he higher expectations of those better situated are just if and only if they work as part of a scheme which improves the expectations of the least advantaged ineinbers of society."). 
deems pragmatist (i.e., instrumentalist) approaches, ${ }^{32}$ that in a representative democracy, judges lack both the legitimacy and the expertise to perform the task my putative theory would assign them. This is a normative argument that I (or the Justices) may or may not find convincing. Yet if I do not find the normative argument convincing, why would I be convinced by the fact that other theorists do? I have advanced my theory precisely because I disagree with theirs. If I were persuaded by one of their theories, I would have adopted it.

Note that I am not offering an argument against all practice-based constitutional theory. I am only offering an arguinent against an exclusively practice-based constitutional meta-theory. (As I have said, a constitutional meta-theory will also be a theory, but a constitutional theory need not be a meta-theory.) The reason I do not offer an argument against all practice-based constitutional theory is that such arguments can be easily defeated. Consider, for example, the resistance that originalists offer to practice-based theory. When faced with the fact that their theory may require the overruling of landmark precedents upholding paper money, upholding the regulatory state, or invalidating racial segregation, some originalists have the courage of their convictions: ${ }^{33}$ with respect to nonoriginalist precedents, they say, in essence, good riddance. They reject the practice. However, when the originalist takes this stance, we may advance one or more of the following arguments agamst his position: it would lead to terrible consequences by upsetting the existing social and political order; it would produce particular results, such as the overruling of Brown $v$. Board of Education, ${ }^{34}$ that would be morally disastrous; and it would violate a moral primciple of integrity in adjudication. Whether or not convincing, each of these claims offers normative grounds for why any good constitutional theory should fit the practice of constitutional law.

But even though we can give good normative reasons why constitutional theory should fit the practice of constitutional law, there is no obvious reason why any good constitutional theory should fit the practice of other constitutional theories. To be sure, one can imagine such claims. Perhaps we think that any proposition believed by the overwhelming majority of constitutional theorists is likely to be true. Or perhaps we think that there is a value to uniformity in constitutional theories. But these are bizarre claims at best, and I do not read Fallon to be advancing them or anything like them. The normative aspect of Fallon's meta-theory consists of three paragraphs in which he argues that the rule of law, political

32. See Fallon, supra note 1 , at 573-74.

33. See, e.g., Earl M. Maltz, A Dissenting Opinion to Brown, 20 S. ILL. U. L.J. 93, 93 (1995) (arguing that Brown v. Board of Education, 347 U.S. 483 (1954), is wrongly decided on originalist grounds).

34. 347 U.S. 483 (1954). 
democracy, and individual rights are worthwhile values, ${ }^{35}$ and a few more in which he contends that other values can be described in terms of these three. ${ }^{36}$ In other words, on close inspection, his meta-theory turns out to be primarily descriptive. Whether it succeeds therefore depends on how good a job it does of capturing the agreement and divisions that exist among constitutional theorists and practitioners. Let us turn to that question.

\section{II}

\section{The Thin Consensus In Constitutional Theory}

Fallon's descriptive thesis is that constitutional theorists with widely different substantive and inethodological approaches share a commitment to the rule of law, democracy, and mdividual rights. When we examine the application of various theories in difficult cases, however, we find remarkably little consensus. To put the point differently, we find that agreeinent (at a very high level of generality) about the constitutional values identified by Fallon pales in significance when contrasted with the disagreeinent about particulars.

I noted above that different constitutional theorists give different priorities or weights to different values. ${ }^{37}$ To illustrate the degree of disagreement, consider the question whether a state's use of sex classifications should be presumptively unconstitutional under the Equal Protection Clause. An originalist would find this a relatively easy question. In 1868, sex classifications were widely understood to be consistent with equality (on a separate spheres rationale), and the Fourteenth Amendinent itself contains an express sex classification. ${ }^{38}$ Thus, an originalist has no occasion to ask whether state-sponsored sex discrimination comports with a morally defensible set of individual rights. ${ }^{39}$ On the other hand, a process

35. See Fallon, supra note 1 , at 558-59.

36. See id. at 559-62.

37. See supra text accompanying notes 19-22.

38. See U.S. CoNsT. amend. XIV, $\S 2$ (providing a penalty for a state's disenfranchisement of "male inhabitants"). Note that section two of the Fourteenth Amendinent does not support a textualist argument against finding gender equality in section one's equal protection clause, because section two is no longer operative text, having been superseded by the Fifteenth Amendment. A textualist argument against gender equality could be built on the basis of the Nineteenth Amendment, however. If it required a constitutional amendment to extend the franchise to women, this argument goes, the Equal Protection Clause does not by itself apply to sex discrimination. See Scalia, supra note 19, at 47 . The argument is not especially strong, however, because the Nineteenth Amendinent prohibits sex discrimination in voting in the exact same terms by which the Fiftecnth Amendment prohibits race discrimination in voting. It would be perverse to read the Fifteenth Amendment to negate an inference that the Fourteenth prohibits most other forms of race discrimination. One might try to distinguish race and sex on normative or historical grounds, but then one has left the domain of textualist argumcnt.

39. See, e.g., United States v. Virginia, 518 U.S. 515, 566-70 (1996) (Scalia, J., dissenting) (arguing that the Virginia Military Institute's exclusion of women should be upheld on the ground that it reflects a continuing tradition of single-sex education pre-dating the adoption of the Fourteenth Amendment). 
theorist like Ely might endorse an equal right to political participation of uncertain scope because he values the democratic process above determinate answers. ${ }^{40}$ However, process theorists would likely join originalists and other formalists $m$ rejecting a more substantive version of equality that a rights-foundationalist might endorse as the pre-condition to the state's exercise of coercive power and to the individual's ability to participate fully in the political process.

Any nuunber of other examples could be given in which a constitutional theory subordinates one or more constitutional values to what the theory treats as the main principle. True, no theory does so in all cases. Justice Scalia, for example, notes that originalists turn faint-hearted when faced with truly reprehensible results, ${ }^{41}$ and theorists of all stripes will permit a role for subordinate values when their value of choice gives ambiguous guidance. But to call the resulting theoretical cacophony a consensus is like saying that there is a consensus that moral theory combines elements of utility and rights because rights-foundationalists allow decisions of policy to be made on the basis of aggregate utility when no rights are at stake and many utilitarians would maximize aggregate utility by recognizing legal rights. Such characterizations achieve accuracy by flattening out crucial differences ainong competing theories.

In denymg that there exists the degree of consensus among constitutional theorists that Fallon claims, I do not deny that there exists consensus about some important matters of constitutional law. For example, nearly all constitutional theorists (as well as judges and lawyers) accept that a constitutional theory must deem the Court's decision in Brown v. Board of Education correct, ${ }^{42}$ while deeming Lochner v. New York ${ }^{43}$ mistaken. ${ }^{44}$ Similarly, nearly all constitutional theorists, judges, and lawyers accept that the Supreme Court would lack the authority to invalidate a

40. Note that Ely himself grudgingly endorses the Supreme Court's unwillingness to tolerate major departures from the principle of one-person/one-vote on the ground that any other rule would be difficult to administer. See Ely, supra note 18, at 121 ("[A]dministrability is [the] long suit [of the oneperson/one-vote principle], and the more troublesome question is what else it has to recommend it.").

41. See Antonin Scalia, Originalism: The Lesser Evil, 57 U. CIN. L. Rev. 849, 862 (1989).

42. See David A. Strauss, What Is Constitutional Theory?, 87 CALIF. L. Rev. 581, 584 (1999). (describing "the legitimacy of Brown" as "absolutely rock solid"). There are some exceptions. See, e.g., RaOul Berger, Governient by Judiciary: The Transformation of the Fourteenth AMENDMENT 132-54 (1997); Maltz, supra note 33, at 93. However, for the most part, originalists twist their theory to accommodate Brown. See Michael C. Dorf, A Nonoriginalist Perspective on the Lessons of History, 19 HARv, J.L. \& PUB. PoL'y 351, 357 (1996) (observing that most self-described originalists attempt to explain away the substantial evidence that the Framers of the Fourteentl Amendment did not intend to end segregation, im order to avoid the embarrassment of embracing an interpretive methodology that produces the wrong result in a seminal case).

43. 198 U.S. 45 (1905).

44. Bruce Ackerman may be an exception. As part of his larger project of recapturing constitutional politics for democratic movements, he argues that Lochner accurately reflected the prevailing understanding of its era. See Bruce Ackerman, Liberating Abstraction, 59 U. CHI. L. REv. $317,339-41$ (1992). 
constitutional amendment that was duly ratified in accordance with Article Five, even if the amendment fundamentally changed the character of our system of government. ${ }^{45}$ But these are relatively easy questions, whereas constitutional theories, if they are to be of prescriptive use, should provide guidance in difficult cases.

For example, consider the question of whether, and under what circumstances, the Constitution imposes affirmative obligations on government. At a general level, Fallon's constitutional values speak directly to this question. Begin with rights. A morally defensible view of rights might well eschew the distinction between positive and negative rights, recognizing the baseline problems inherent in drawing this division. Even a newspaper's right to publish without interference from the government-a seemingly negative right-depends on a web of government action protecting, among other things, the newspaper's property and contracts. ${ }^{46}$ Conversely, an individual's effective exercise of the negative right to free speech may require a positive entitlement to education, not to mention food and shelter. On the other hand, concerns about the democratic legitimacy of judges issuing rulings with large allocative effects might lead a court to insist on a conception of negative rights. Finally, the rule of law could be invoked on either side of the question. If we take the baseline problems seriously, then it would appear arbitrary not to extend protection to positive as well as negative rights; yet, given the uncertain content of inost positive rights-what, for example, would a right to health care entail?-the rule of law could as easily be invoked to argue that all judicial protection of positive rights calls for the drawing of arbitrary, unprincipled lines.

Thus, although Fallon's categories speak to the distinction between negative and positive rights, they do so equivocally. Moreover, they provide almost no traction on real constitutional issues involving the putative distinction between negative and positive rights. Must states provide their residents with a minimally satisfactory public education? If they undertake to do so, unust they do so on an equal basis, and how is equality measured $?^{47}$ Do states have an obligation to protect residents against private

45. Ackerman states the prevailing view when he acknowledges the authority of a hypothetical repeal of the First Amendment, and its replacement with a provision stating: "Christianity is established as the state religion of the American people, and the public worship of other gods is hereby forbidden." ACKERMAN, supra note 20, at 14. As James Fleming notes, however, Ackerman arguably elevates a raw fact of political power into a matter of constitutional principle. See James E. Fleming, We the Exceptional American People, 11 Const. Commenr. 355, 361 (1994) (citing JoHn Rawls, Political Liberalism 233 (1993)); see also Jeff Rosen, Note, Was the Flag Burning Amendment Unconstitutional?, 100 YALE L.J. 1073, 1073-74 (1991) (arguing that an amendment could be unconstitutional because it violates natural law).

46. See Cass R. Sunstein, A New Deal for Speech, 17 Hastings Comm. \& ENT. L.J. 137, 138 (1994) (explaining that free speech doctrine rests on the pre-New Deal view that the Constitution prohibits government regulation that disturbs existing distributions of rights).

47. See, e.g., San Antonio Indep. Sch. Dist. v. Rodriguez, 411 U.S. 1 (1973) (rejccting an equal protection challenge to Texas's system of funding public education). 
violence ${ }^{48}$ If not, are there circumstances under which the government's assumption of such responsibilities makes it respons-ible for otherwise private wrongs? One cannot evade such questions by saying that the Constitution protects only negative liberty, because as we saw, the basic difficulty inheres in distinguishing between negative and positive liberty, at least iu the borderline cases, which are the ones to which constitutional theory ought to speak. To say that various constitutional theories will answer such questions by emphasizing various conceptions of Fallon's three values tells us very little about how different theories actually resolve such questions.

III

VALUES Other than FaLlon's Three CRITERIA

I have argued thus far that, stated at the level of abstraction at which Fallon states them, his three constitutional values are largely indeterminate. Suppose one were to disagree. Fallon would still face the difficulty of accommodating other values. If Fallon allows that a limitless class of other values also inform - and thus can be made to serve as the evaluative criteria for-constitutional theory, he surely falls prey to the charge of mdeterminacy, not to mention banality. For then Fallon's claim would reduce to the trivial assertion that constitutional theorists all agree on the need for constitutional adjudication to serve some combination of values.

On the other hand, for Fallon to exclude other values from his account would render it incomplete, because constitutional adjudication, and therefore constitutional theory that seeks to be descriptively accurate, aims not only for primcipled solutions, but also workable ones. Fallon acknowledges that "it is an obvious concern whether a particular theory would permit a 'workable' government that can respond effectively to changing needs and exigencies, ${ }^{349}$ but omits such concerns from his catalogue of principal constitutional values because he believes they can be subsumed, however awkwardly, within his three categories. ${ }^{50}$

The crucial question for Fallon's meta-theory, therefore, is whether constitutional theory does better by channeling-and thus potentially distorting-all value arguments through the three values he identifies. Fallon's approach may be right. It may be better for the practice of constitutional law if some kinds of values and arguments are einployed only indirectly. I would suggest, however, that considerations of governmental

48. See, e.g., DeShaney v. Winnebago County Dep't of Soc. Servs., 489 U.S. 189 (1989) (finding no constitutional violation in govcrnment agency's failure to remove a child from a severely abusive hoine).

49. Fallon, supra note 1, at 559.

50. See id. at 559. 
efficacy play more than a minor or indirect role in constitutional adjudication.

Judge Posner recently remarked on the ubiquity of policy analysisalbeit uninformed and rather shoddy policy analysis-in Supreme Court adjudication. ${ }^{51} \mathrm{~A}$ few examples illustrate the claim. The Justices who espouse the ideal of a color-blind Constitution contend that affirmative action programs tend to perpetuate racial divisions, ${ }^{52}$ whereas those who would uphold such programs contend that they are necessary to overcome a legacy of discrimination. ${ }^{53}$ The Justices who believe the Constitution contains no judicially enforceable federalism limits contend that the structure of the national government will protect state sovereignty ${ }^{54}$ whereas those who disagree believe that members of Congress will systematically overvalue national interests. ${ }^{55}$ And to choose an example of doctrinal consensus, the Court will invalidate speech licensing requirements that vest unbridled discretion in a government official because the Justices believe that such officials will systematically undervalue free speech, while overvaluing public order, or worse, restricting unpopular expression. ${ }^{56}$

In each of the foregoing examples, and the many more that could be adduced, the policy consideration identified mixes empirical assumptions with values. Furthermore, in each example, constitutional adjudication turns on matters besides the ones I identify. Constitutional adjudication rarely turns purely on policy grounds, nor should it. Thus, I agree with Fallon that praginatism is not a compelling constitutional theory if praginatism ineans pure instrumentalism - that is, deciding cases solely on the basis of what one thinks will lead to the best result, however defined. But it hardly follows that instrumental considerations play no role in constitutional adjudication. They play a substantial one, and properly so. ${ }^{57}$

51. See Richard A. Posner, Against Constitutional Theory, 73 N.Y.U. L. REv. 1, 11-12 (1998).

52. See, e.g., Adarand Constructors, Inc. v. Pena, 515 U.S. 200, 239 (1995) (Scalia, J., concurring in part and concurring in the judgment) ("To pursue the concept of racial entitlement-even for the most admirable and benign of purposes-is to reinforce and preserve for future mischief the way of thinking that produced race slavery, race privilege and race hatred.").

53. See, e.g., Regents of the Univ. of Cal. v. Bakke, 438 U.S. 265, 407 (1978) (Blackmun, J., separate opinion) ("In order to get beyond racism, we must first take account of race.").

54. See, e.g., Garcia v. San Antonio Metro. Transit Auth., 469 U.S. 528, 550-51 (1985) (Blackmun, J., joined by Brennan, White, Marshall, and Stevens, JJ.) ("It is no novelty to observe that the composition of the Federal Government was designed in large part to protect the States from overreaching by Congress.").

55. See, e.g., id. at 560-61 (Powell, J., dissenting, joined by Burger, C.J., and Rehnquist and O'Connor, JJ.) (lamenting that under the majority's view, "the role of the States in the federal system may depend upon the grace of elected federal officials").

56. See, e.g., City of Lakewood v. Plain Dealer Publ'g Co., 486 U.S. 750, 757 (1988) ("'I]n the area of free expression a licensing statute placing unbridled discretion in the hands of a government official or agency constitutes a prior restraint and may result in censorship.").

57. See Michael C. Dorf, The Supreme Court, 1997 Term-Foreword: The Limits of Socratic Deliberation, 112 HARv. L. REv. 4, 37-38 (1998) (discussing the Supreme Court's limited use of empirical data ì addressing instrumental concerns). 
I might thus offer what appears to be a friendly amendment to Fallon's meta-theory: in addition to the three criteria he identifies, he should add a category for considerations of efficacy. However, Fallon cannot view the amendment as friendly because, as we have seen, accepting it would inake Fallon's ineta-theory untidy and indeterminate. As the number of criteria by which constitutional theory is judged increases, the criteria look less like a meta-theory and inore like an admission that one has no metatheory.

\section{IV}

\section{AlgoRITHMS AND PHILOSOPHICAL PRAGMATISM}

Throughout this Reply I have been at pains to distinguish between pragmatisin-as-contextualisin-which I deein an appropriate approach to constitutional interpretation - and pragmatism-as-instrumentalisin-which appears to be Fallon's least favorite constitutional theory. In this Part, I explore the respective roles of these two conceptions of praginatisin in Fallon's acconnt of constitutional theory. To do so, I consider a theory of constitutional adjudication that Fallon offered a decade ago.

In A Constructivist Coherence Theory of Constitutional Interpretation, ${ }^{58}$ Fallon argued that constitutional adjudication recognizes as legitimate five kinds of arguments, based on: (1) the text's plaim meaning; (2) the intent of the Framers; (3) constitutional theory; (4) precedent; and (5) claims of justice or social policy..$^{59}$ Fallon claimed further that within the practice of constitutional law, these five forms of argunent overlap and inter-penetrate. Accordingly, justices, lawyers, and scholars understand their task $m$ any given case as using each of the various forms of argunent to support a unique result. ${ }^{60}$ Thus, although in principle "[c]onstitutional law has a commensurability problem," the rare judicial opinion, the anomalous brief, the unusual scholarly analysis that describes the relevant kinds of arguments as pointing in different directions." 62

Because such clashes are inerely rare rather than nonexistent, Fallon believed himself obligated to offer a prescription for those cases in which the forms of arguunent could not be made to align. Fallon's proposed solution was a hierarchy of constitutional arguments, ranking them in the order set forth above. ${ }^{63} \mathrm{I}$ believe this was a mistake, not because I would prefer soine other hierarchy of constitutional arguinents, but because our

58. Richard H. Fallon, Jr., A Constructivist Coherence Theory of Constitutional Interpretation, 100 HARV. L. REV. 1189 (1987).

59. See id. at 1189-90.

60. See id. at 1238-43.

61. Id. at 1189 .

62. Id. at 1193 .

63. See id. at 1244-46. 
constitutional practice is too multi-faceted to be captured by an all-purpose algorithm, and appropriately so. In some cases where forms of argument lead to an irreconcilable conflict, text will be deemed controlling, ${ }^{64}$ in other cases precedent, ${ }^{65}$ and in other cases still, normative considerations. ${ }^{66}$

Fallon's discussion of Brown illustrated the basic difficulty with his approach in $A$ Constructivist Coherence Theory. He began by frankly acknowledging that "the point of departure ... lies im the conviction that the state-enforced segregation of school children is morally and politically wrong." This seemed an odd starting point, given that normative considerations supposedly played the smallest role in Fallon's approach. To be sure, the text, which plays the largest role, is legitimately ambiguous. ${ }^{68}$ Yet what of the Framers' intent, which Fallon treated as second in the hierarchy? Fallon acknowledged that there is substantial evidence that the Framers of the Fourteenth Amendment intended to permit racially segregated schools. ${ }^{69}$ In order not to give that fact controlling weight, he suggested that the Framers' intent be understood in very general terms or that we consider whether the Framers objected to the possibility that judicial interpretations of the Equal Protection Clause might evolve. ${ }^{70}$ Coherence was achieved and thus Fallon avoided the embarrassment of a theory that could not account for the most miportant case of the twentieth century, but only just barely. Did Fallon really mean to suggest that the Framers' intent would be dispositive even if it could not be made to cohere with the normatively desirable outcome in Brown? That unfortunate outcome was the implication of his hierarchy, which may explain why A Constructivist Coherence Theory did not even attempt to provide an account of Bolling $v$. Sharpe ${ }^{71}$ the compamion case to Brown. In Bolling, the Court held that the Fifth Amendment's Due Process Clause, ratified by slaveholding states in 1791, proscribed de jure racial segregation in District of Columbia public

64. For example, there are sound policy reasons for conducting bench trials in patent cases; yet on the basis of the Seventh Amendment's text, the Supreme Court states unequivocally that patent "infringement cases today must be tried to a jury, as their predecessors were more than two centuries ago." Markman v. Westview Instruments, Inc., 517 U.S. 370, 377 (1996).

65. See, e.g., Planned Parenthood v. Casey, 505 U.S. 833, 846 (1992) ("Although a literal reading of the [Due Proccss] Clause might suggest that it governs only the procedures by which a State may deprive persons of liberty, for at least 105 years . . . the Clause has been understood to contain a substantive coinponent as well, one 'barring certain governinent actions regardless of the fairness of the procedures used to inplement them."' (citing Mugler v. Kansas, 123 U.S. 623, 660-61 (1887), and quoting Daniels v. Williams, 474 U.S. 327, 331 (1986))).

66. See infra text accoinpanying notes 67-72.

67. Fallon, supra note 58 , at 1278.

68. See id. at 1279 ("The fourteenth amendment's guarantee of equal protection of the laws certainly will support, even if it does not require, an interpretation that forbids racially segregated public schools.").

69. See id.

70. See id at $1280-82$.

71. 347 U.S. 497 (1954). 
schools, essentially because the contrary result would have been "unthinkable." "72

Fallon's constructivist coherence theory could not be salvaged by rearranging the priority he assigned to various forms of argument. In most cases, text-based arguments will appropriately trump other forms of argument, and the intent of the Framers will often trump conflicting normative arguments, especially im the period shortly after a constitutional provision's adoption. ${ }^{73}$ No all-purpose hierarchy will explain which form of argument to prefer when coherence cannot be achieved.

Moreover, there was an even more basic problem with Fallon's constructivist coherence theory: coherence can often be achieved for a variety of conflicting results. Fallon defended Brown by beginning with normative arguments and then tweaking other forms of argument; yet he might as easily have begun with precedent-based arguments and then tweaked the other forms in the direction of Plessy v. Ferguson, ${ }^{74}$ rather than Brown. Fallon offered no account of where the Court should begin its search for coherence, and for the same reason that there is no all-purpose hierarchy of forms of argument when they conflict irreconcilably, there is no allpurpose hierarchy when multiple patterns of coherence are possible.

By reading A Constructivist Coherence Theory in the light of Fallon's contribution to this Volume, perhaps we can see why Fallon adopted an untenable approach in the earlier article. To admit that no formula can guide constitutional adjudication in all cases is to endorse something very much like philosophical pragmatism, that is, contextualism. As I indicated in the Introduction, there is a tendency among legal scholars to confuse pragmatism-as-contextualism with pragmatism-as-instrumentalism. ${ }^{75} \mathrm{I}$ do not want to say that Fallon himself commits this error: How to Choose a Constitutional Theory uses the term pragmatism consistently to mean imstrumentalism; it never expressly invokes the philosophical concept of pragmatism-as-contextualism at all. Nevertheless, I would guess that Fallon's rejection of pragmatisin-as-contextualism rests to some degree on his rejection of pragmatism-as-instrumentalism, and understandably so. For even though pragmatism-as-instrumentalism and pragmatism-ascontextualism are distinct concepts, they share an important

72. Id. at 500 .

73. See Dorf, supra note 22 , at $1816-22$ (arguing that respect for popular sovereignty suggests that original understanding should play a greater role in interpretation in the period immediately after a constitutional provision's enactment than at a later time, when the original understanding no longer reflects the views of the people and other circumstances will likely have changed as well).

74. 163 U.S. 537 (1896).

75. As $\mathrm{I}$ have noted elsewhere, Oliver Wendell Holmes, "who played the leading role in introducing pragmatism into the law, bears substantial responsibility for the association of pragmatism with instrumentalism." Dorf, supra note 57, at 81 n.433. 
commitment: both are anti-theoretical in the sense that both versions of pragmatism deny that practices must be grounded $m$ any foundation. ${ }^{76}$

The prospect of sacrificmg all foundations makes Fallon uneasy. In $A$ Constructivist Coherence Theory, the uneasiness led him to back up his otherwise coherentist framework (pragmatism-as-contextualism) with an algorithm. In How to Choose a Constitutional Theory, the uneasiness leads him to conclude that pragmatism (as instrumentalism) is a poor constitutional theory because he believes it "offends both rule-of-law and democratic values... [and] would also devalue the notion of a constitutional "right.",77

It should be clear by now that I have a somewhat more sanguine view of the role of both sorts of pragmatism in constitutional theory. I believe that pragmatism-as-contextualism is a fair description of much constitutional adjudication, and mdeed of much of American jurisprudence more generally. And while I agree with Fallon that pure instrumentalism is an inappropriate approach to adjudication, I would recogmize a greater role than he would for imstrumental considerations.

I do not offer anything like a full defense of either of these positions here, ${ }^{78}$ but I do need to respond to a potential objection. I noted above that the rejection of thoroughgomg instrumentalism in constitutional adjudication should not properly entail a rejection of all instrumental considerations. Yet, it could be argued, my account of constitutional adjudicationin which the weight to be given various factors cannot be fully specified outside the context of particular cases-really is thoroughgoing instrumentalism, because the choice of how to proceed in any given case is made by an all-things-considered judgment. For example, even if the Court deems the Framers' mtent dispositive in a particular case, the decision to give controlling weight to the Framers' intent is made on instrumental rather than formal grounds.

The answer to this objection is that any attractive theory turns out to be "ultimately" instrumental, because part of a theory's appeal is that it produces acceptable results. An approach to adjudication that considers consequences directly only creates special problems if it is completely porous to its background justifications, so that the decision in each case

76. Daniel Farber expressly links what I am calling legal pragmatism (instrumentalism) with philosophical pragmatism (contextualism) by emphasizing anti-foundationalism in constitutional adjudication. See Daniel A. Farber, Legal Pragmatism and the Constitution, 72 MINN. L. REv. 1331, 1332 (1988) ("Legal pragmatism-which essentially means solving legal problems using every tool that comes to hand, including precedent, tradition, legal text, and social policy-renounces the cntire project of providing a theoretical foundation for constitutional law.").

77. Fallon, supra note 1 , at 574 .

78. I recently explored the role of pragmatism in institutional design and legal interpretation. See Michael C. Dorf \& Charles F. Sabel, A Constitution of Democratic Experimentalism, 98 CoLum. L. REv. 267, 284-86 (1998) (institutional design); Dorf, supra note 57, at 80-83 (constitutional and statutory interpretation). 
amounts to no more than an all-things-considered judgment. ${ }^{79}$ Fallon (or someone else) might say that pragmatism-as-contextualism in constitutional adjudication as I have described it has precisely this problem: the choice of what forms of argument to emphasize in any given case is made on purely instrumental grounds. But this is not true. The fact that we cannot specify an all-purpose algorithm that tells us which forms of argument to emphasize does not mean that the choice is unconstrained. The choice of emphasis among forms of argument is very much constrained by the entire practice of constitutional adjudication.

When I say that constitutional practice constrams the Court, I do not mean to say that the practice uniquely determines the degree to which the Court may emphasize one form of argument or another, any more than it umiquely determines outcomes in difficult cases. But a lack of complete determinacy is not the same thing as indeterminacy. For example, the Court could plausibly find that the possession of a firearm in the vicinity of a schoolyard bears an insufficiently close relation to interstate commerce to fall within Congress's power to regulate, ${ }^{80}$ but it could not plausibly find that Congress lacks the power to charter a bank, even though James Madison and Thomas Jefferson held that view at the Founding. ${ }^{81}$ Hence, even though there may be sound textual, structural, and originalist grounds for a substantial scaling back of the scope of the Commerce Clause, even the most reactionary Justice would not dare advocate overturning Marshall Court decisions that were expansive in their day, ${ }^{82}$ no matter how hostile he might be to federal power. We cannot point to any reason external to constitutional practice that explains why precedent takes priority in this example; and yet that result will seem incontestable to nearly anyone who takes part in the practice.

\section{CONCLUSION}

Works of philosophy that use the full arsenal of philosophical argument to demonstrate that the philosophical enterprise is ultimately pointless, or works of legal theory that do the same for legal theory seem at least a hittle odd. ${ }^{83}$ Why, one wants to ask, does the author not simply engage in the activities he deeins worthwhile? Because this Reply may leave the

79. Cf. Frederick Schauer, Playing by the Rules: A Philosophical Examination of Rule-Based Decis1on-MAKING IN LAW AND IN L1FE 108-11 (1991) (explaining that formalism typically requires that a decisionmaker follow a rule rather than the background justification for the rule).

80. See Lopez v. United States, 514 U.S. 549 (1995).

81. See Geoffrey R. Stone ET AL., Constitutional Law 67 (2d ed. 1996).

82. See Lopez, 514 U.S. at 593-96 (Thomas, J., concurring) (accepting the authority of Gibbons v. Ogden, 22 U.S. (9 Wheat.) 1 (1824)).

83. See, e.g., Richard Rorty, Philosophy AND THE Mirror of NATURE (1979) (philosophy); DeNNis Patterson, LAW AND TRUTH (1996) (law). 
impression that I think there is no need for constitutional theory-that it is enough (for the Supreme Court) just to decide cases-I should explain why I think that meeting claims of (or about) constitutional theory is a worthwhile enterprise. The answer is that I do not believe that constitutional theory is worthless, and I certainly have offered no argument for that position here. What I have argued is that to find-I do not say "choose"-a satisfactory constitutional theory, one must leave the domain of theory qua theory, and grapple with the very real and very interesting challenges that plain old constitutional law presents. 